\title{
Itinéraires Itinéraires
}

Littérature, textes, cultures

2019-1 | 2019

La « renaissance littéraire » africaine en débat

\section{"Le pays, c'était comme la femme d'un autre": Reconceptualising West African Migrant Masculinity in Fatou Diome's Le Ventre de l'Atlantique and Léonora Miano's Tels des astres éteints}

"Le pays c'était comme la femme d'un autre " : reconceptualiser la masculinité des immigrés de l'Afrique occidentale dans Le Ventre de l'Atlantique de Fatou Diome et Tels des astres éteints de Léonora Miano

\section{Ashwiny 0. Kistnareddy}

\section{OpenEdition} Journals

Electronic version

URL: http://journals.openedition.org/itineraires/6086

DOI: $10.4000 /$ itineraires.6086

ISSN: 2427-920X

Publisher

Pléiade

Electronic reference

Ashwiny O. Kistnareddy, "Le pays, c'était comme la femme d'un autre": Reconceptualising West African Migrant Masculinity in Fatou Diome's Le Ventre de l'Atlantique and Léonora Miano's Tels des astres éteints », Itinéraires [Online], 2019-1 | 2019, Online since 18 July 2019, connection on 01 August 2019. URL : http://journals.openedition.org/itineraires/6086 ; DOI : 10.4000/itineraires.6086

This text was automatically generated on 1 August 2019.

\section{(i) $\$$

Itinéraires est mis à disposition selon les termes de la licence Creative Commons Attribution - Pas d'Utilisation Commerciale - Pas de Modification 4.0 International. 


\title{
"Le pays, c'était comme la femme d'un autre": Reconceptualising West African Migrant Masculinity in Fatou Diome's Le Ventre de l'Atlantique and Léonora Miano's Tels des astres éteints
}

\author{
"Le pays c'était comme la femme d'un autre " : reconceptualiser la masculinité \\ des immigrés de l'Afrique occidentale dans Le Ventre de l'Atlantique de Fatou \\ Diome et Tels des astres éteints de Léonora Miano
}

Ashwiny 0. Kistnareddy

\section{Introduction}

Fatou Diome and Léonora Miano, born in Senegal and Cameroon respectively, and living in France, are part of the growing number of diasporic African writers seeking to transform the landscape of African literature. Diome is a prolific writer whose novel Le Ventre de l'Atlantique (2003), translated in 2008 under the title The Belly of the Atlantic, has garnered a great deal of success due to its humoristic and yet poignant description of African migrants' life in France. Miano is a novelist, essay writer and now a theorist, with Marianne et le garçon noir (2017). In Tels des astres éteints (2008) Miano discusses the troubling dislocation experienced by African migrants in France through three distinct voices. In this article, I examine the emerging notions of masculinity in relation to subSaharan African migrants in Paris in the novels, to gauge the extent to which the women writers are reconceptualising masculine identity and thus debunking erstwhile notions of masculinity. 
2 In his seminal Peau noire masques blancs (1952), Fanon declares that "What we call the Black soul is a White man's invention" (Fanon 1952: 11). ${ }^{1}$ Black masculinity itself was severely compromised by White colonizers given that colonization assumed the position of the male penetrating the feminized colonial country. As Connell has underlined, "the colonizer was virile and the colonized were dirty, sexualized, and effeminate, or childlike" (Connell [1995] 2005: 75). She further adds that "it follows [...] that decolonization and transition to a postcolonial world are likely to involve problems about masculinity and violence" (76). For the theorist, "reconstruction is not the work of men alone [...] women are active in the shaping of masculinities" (76). ${ }^{2}$ This article gauges the extent to which Miano and Diome reshape African masculinities in post-colonial, contemporary France, where nationalism and the need to assert "French" identity has become more prominent.

3 Linked to the shift in perceptions of masculinity are the notions of nostalgia and return in the context of the diaspora in the novels. Diasporas take on many shapes throughout history, from the dispersion of Jews, to the modern day socio-economic migrations, which have fostered new diasporic communities in several parts of the world, via the forced "collective trauma" of slavery for Africans for instance, as Cohen explains in Global Diasporas: An Introduction. For Cohen, "all diasporic communities [...] acknowledge that 'the old country' [...] always has some claim on their loyalty and emotions" (Cohen 1997: ix). For socio-economic migrants whose displacement is recent, the sentiment of nostalgia is equally ever present.

4 According to Boym, "nostalgia is a longing for home, but often a longing for a home that no longer exists, or perhaps has never existed" (Boym 1995: 75). This discrepancy between the idealised home and the actual home, or lack thereof, is complicated in the context of diasporas wherein the individuals involved feel out of place both in the diasporic surroundings and the home for which they experience nostalgia. Often coupled with the notion of nostalgia is that of the return to the home, which as Boym states, is absent or was never present. The return itself is seen from the diasproric point of view through the terms "ethnic return migration" or "return migration" (Tsuda 2009). In the context of migration undertaken predominantly by men, it is crucial to examine the extent to which nostalgia and return reshape the notion of masculinities. Moreover, the tension between the new home and the original home and their role in identity construction is analysed to demonstrate whether the emergent Black masculinities depicted are emblematic of a new way of conceptualising masculinity.

\section{Black Masculinities in White Paris}

5 In the years post-independence, socio-economic migration from former colonies to France has increased exponentially. The journey to Paris has often been undertaken by men, ${ }^{3}$ seeking to escape poverty and send money back to Africa. The effect of such mobilities on the notion of identity as conceived by migrant men becomes a crucial aspect to be considered. As a means of decentring his analysis from the Western family structure in order to provide a different perspective on masculinity, Bourdieu examines the positioning of men in Kabyle society in La Domination masculine (1998). Bourdieu underlines the place occupied by men in such societies where the male dominates the social realm while the female is constrained to the domestic space. This model is frequently seen in non-Western societies where public and private spaces have been 
divided into male and female respectively. Nonetheless, in Miano's and Diome's texts, this hegemony is accompanied by the responsibility placed on sub-Saharan men, regardless of their age, to earn money and feed their extended families. ${ }^{4}$

For Diome, in Le Ventre de l'Atlantique:

Most of these boys only receive mouths to feed as inheritance. Despite their youthfulness, many are already heads of extended families and they are expected to achieve what their fathers failed to do: get their families out of poverty. They are harassed by responsibilities that confound them and lead them to desperate solutions. (Diome [2003] 2005: 182) ${ }^{5}$

Similarly, Miano, in Tels des astres éteints underscores the exhaustion of migrants whose only concern remains sending money back to their communities, to the detriment of their own health and wellbeing (Miano [2008] 2010: 30). Both writers unveil the suffering of migrant Black men whose sense of identity is caught between the need to support their family and the overwhelming necessity to find their place in a host society that petrifies them in their difference.

From this perspective, Cazenave and Célérier argue that migration and displacement is "no longer a collective political struggle, but an isolated, individual, and fragmented process" (Cazenave and Célérier 2011: 11). The fragmentation observed by the critics is symptomatic of a generation of migrants who are split between their home country and their host country. Visibly different, they are both physically and psychologically displaced as they are excluded from French society in the novels. This is exacerbated by the nostalgia that these men experience vis-à-vis the left-behind home, and the superior public position they occupied in their society of origin, following Bourdieu's analysis.

8 For Cazenave and Célérier, "Diome's novel proposes a critical rereading of the myth of France as a haven for immigrants, the path to social recognition, and the exit-door to thwarted possibilities on the continent" (Cazenave and Célérier 2011: 123). While Cazenave and Célérier are right to underline the critical point of view adopted by Diome, it is imperative to understand that Diome also provides a different and layered vision of the men who are struggling to make sense of their own position in society. Similarly, writing about Miano's text, Cazenave and Célérier observe "[Miano] evokes the impossibility of going back home and, in the process denounces the myth of Paris/France as the land of plenty. [...] Each narrative reasserts French society's refusal to deal with the postcolonial subject and her/his agency" (Cazenave and Célérier 2011: 125). ${ }^{6}$ Ndiaye, who attempts a sociological study of "The Black condition" in French society asserts that "we must reveal this paradox: black people in France are individually visible, but they are invisible as a social group and have not yet received particular attention from researchers" (Ndiaye 2008: 21).

In a country that publicly denies race-the Constitution until July 2018 stipulated that there should be no distinction of race or origin-it is difficult to process and examine racial discrimination as race is not recognised as existent. ${ }^{7}$ The French MPs' recent decision to remove race from the constitution completely further adds to this issue as there is now no avenue to discuss or denounce racism and its effects on migrants in France. How then do these men negotiate a thwarted masculinity, a denied subjectivity in the face of racism as well as a nostalgia for their "home" country? 


\section{Failed Returns to Africa: Black Masculinities in Limbo}

10 According to Boym, the feeling of nostalgia is closely associated with the diaspora insofar as it is marked by the need to feel at home. Thus, it is not a longing for a place as such, but the feeling of intimacy associated with the place (Boym 2001: 258). For Boym, there are two types of nostalgia: the first is "restorative," based on a collective sense of a national project oriented on the past and the second is "reflective," individual, focused on the future. Boym's distinction is significant as it foregrounds both the identity of the diaspora and the affective aspect of nostalgia, which in the case of the novels is explored through the prism of skin colour and masculinity.

11 Thus, in Miano's Tels des astres éteints, the opening narrator, who has the status of observer in this polyphonic novel, comments on the centrality of colour in identity construction in French society: "here only colour defines us [...] it isn't merely our clothing, it's our totality" (Miano [2008] 2010: 15). The novel paints the portrait of a fractured society which is unable to accept the strangers in its midst. Countries such as the UK and France have a problematic relationship with their colonial past and as such, they efface the rhetoric of colonialism from their discourse, as Ndiaye has remarked in $L a$ Condition noire (2008).

12 For Gilroy in Postcolonial Melancholia (2000), when descendants of the colonized make the reverse journey from the periphery to the centre, putting former Colonial societies face to face with evidence of their guilt, "postcolonial melancholia" manifests itself. Whilst they cannot deny their past, they simultaneously refuse to acknowledge it, causing a tension with the migrant other. On the other hand, Etoke looks at melancholia in the concept of "melancholia africana" and examines how the "loss, mourning and survival" experienced by Afrodescendants and Subsaharan African migrants informs their present in a form of contamination (Etoke 2010: 28). ${ }^{8}$ Both the former coloniser and the former colonised thus experience melancholia in different ways and this impacts greatly on the migrant sub-Saharan men who bear the brunt of France's disavowal of colonialism in the texts as well as their own feeling of dislocation.

13 Thus, the principal protagonists in Miano's novel, Amok, Shrapnel and Amandla experience alterity as immigrants in a range of ways. Shrapnel is the quintessential militant Black man from Africa who would like to see changes happening from within France, as it was the inception of racism and the colour divide. Marked by his desire to restore Blackness to humanity (Miano [2008] 2010: 56), Shrapnel envisions a return to the source of Blackness, the Tree of Life, on the African continent. Shrapnel's nostalgia is therefore "restorative" in the sense that Boym explicates it. It is a national project insofar as Shrapnel attempts to re-create a form of national identity. Shrapnel is part of the activist group, Sons of Kemet, which hopes to revolutionize African identity. Yet, Shrapnel's hopes are thwarted by blatant acts of racism and prejudice: French people give him a wide berth and bags are safely tucked away because he is perceived to be dangerous (Miano [2008] 2010: 52) in his blatant Black masculinity.9

Despite this, Shrapnel is attracted to Blonde women who remind him that he is a man, positing white women as redemptive and the conduit towards a recuperation of Black masculinity in Shrapnel's case. The white woman's gaze permits a renegotiation of identity for Shrapnel. Ironically, Shrapnel is emasculated by Black women who value financial stability, since they are pragmatic and need to make ends meet (Miano [2008] 
2010: 109-110). Yet, Shrapnel reveals a racialized view of white women as fantasizing so readily about the idea of the Black man that "it would suffice to blow on them for them to swoon" (Miano [2008] 2010: 219).

In Peau noire, masques blancs (1952) Fanon asserts that Black men from the Caribbean, for instance, feel the need to reaffirm their masculinity by sleeping with a white woman, thus proving their authentic virility. For Fanon, this is symptomatic of neurosis due to abandonment. The individual suffering from this feels the need to validate himself through others because he was abandoned very young. Indeed, Shrapnel has never met his father and has never used the term "father." Whilst it would be simple to map Fanon's theory onto this, it is perhaps more useful to look at it from a second point of view: when Shrapnel fathers a child, which he only legally recognizes because fatherhood would allow him to gain French nationality. Manipulative, Shrapnel thus uses one of Marianne's daughters to gain access to Marianne, but the child itself is in turn abandoned because of Shrapnel's incapacity to love his son. The son becomes a reminder of his own failure to provide a genealogy, a link to Africa for the next generation. "Restorative" nostalgia here impedes "reflective" nostalgia insofar as it disrupts continuity and the future.

This interruption is further exacerbated by Shrapnel's sudden cardiac arrest. The futility of his death underscores the futility of his dream. While Shrapnel has dreamed for the whole of the Black diaspora, he has not lived his own life fully. Shrapnel's out of body experience on his death bed leads him to an in-between world, where the failure of the notion of individual responsibility for collective identity is reinforced by the voices of the great Black men of the history of the Black diaspora: Martin Luther King does not want to hear about his "dream" again because the voices of the people clamouring after his dream compel him to stay in limbo. Similarly, Malcolm X has also found it impossible to pass on to the afterlife. ${ }^{10}$ Miano here takes the reader to a space where the rhetoric of attachment to ancestral values leads to a limbo where the leaders, which include Shrapnel, are forced to relive their inadequacies repeatedly. While theorists like Homi Bhabha (1994), advocate a notion of identity as an in-between space where the individual can slip between the ancestral and the new identity, here diasporic, and find it enabling, in Shrapnel's case the in-between space is a prison for eternity. It is only when Shrapnel recognizes his failure as a father, as an individual, with a personal history, that he attains a higher state and passes on.

The other character who attempts to recreate a narrative for Black people in Miano's text is Amandla, who is also an activist. Amandla's perception of the Black diaspora is stark and reveals a section of society trapped between two realities: that of their material comforts in France and that of their sacred identity in Africa. She observes the fear felt by her peers:

They were afraid to find themselves suddenly on this land that was so easily idealized from afar, where there was no Social security. Afraid to find themselves among people who were not expecting them, who did not know them, and who would not understand why they would leave Babylonia to join what they were eschewing. [...] She knew many people who, born in Kemet, were determined to never return. She saw them every day clinging to the poverty of the North, convinced that it was more glorious than that of Kemet (Miano [2008] 2010: 86-7). ${ }^{11}$

18 Any notion associated to France (Babylonia) remains idealised, even if it is poverty. Amandla promulgates a return to the source of mother Africa (Kemet) through an actual movement to the continent, an ethnic return migration to contextualise it in diasporic 
studies terms. However, to do this, she needs a "mythical man" (Miano [2008] 2010: 81), ${ }^{12}$ since without a man, there would be no family.

Masculinity is strongly linked to nostalgia and the return here as genealogical return can only happen through the coming together of the diasporic woman and native West African Bantu man. The objectification of the man evokes Miano's debunking of stereotypes. Conversely, while Shrapnel would like to use women, he finds himself straying from his path due to the feelings he harbours towards his white girlfriend. In Amandla's case, the Black man becomes a breeder, just as in erstwhile slavery periods where his capacity to procreate was needed along as his physical resilience in the fields. Nevertheless, much as with Shrapnel, Amandla also represents the failure of the return to Africa and an overattachment to an Africa that does not recognize her children. Amandla's return is aborted because her real mother is on her deathbed and all attempts at leaving for Mother Africa must be halted so that she can take care of her real mother. In both Amandla's and Shrapnel's cases, the nostalgic, restorative notion of Africa is reduced to an unaccomplished dream as it was impossible in the first place. While these two characters are preoccupied with negotiating collective identity, their individual circumstances and ultimately their personal history, reduce their endeavours to nothing.

On the other hand, Diome's Le Ventre de l'Atlantique is chiefly homodiegetic alongside several metanarratives, which are told as anecdotes by the narrator. Indeed Salie, the main author-protagonist, tells this story from her point of view, depicting Niodior, Senegal and the life of African migrants in France through individual stories. The "here" and "there" of the narrative is constantly changing, whether it be where Salie lives in Strasbourg, France or in Niodior. Through stories which alternate pathos and humour, as Cazenave and Célérier (2011) pointed out, Salie paints a bleak picture of the life of Black migrants in France.

Thus, the success story of Niodior, who set up a shop on the island "had been a nigger in Paris [...] never did his torrential narratives reveal the miserable existence he lived in France [...] he had first haunted the metro exits, stolen to satiate his hunger, begged, survived through winter thanks to the Salvation Army, before squatting with fellow sufferers" (Diome [2003] 2005: 88-9). ${ }^{13}$ Black men are relegated to the lowest social positions in a society that rejects them as inhuman in the novel. Yet, they cling on desperately due to the number of people counting on them to survive back home.

Moussa, one of the most pitiful characters in the novel, demonstrates the absolute disparity between expectations and life in France: sent to France as a football player, he cannot adapt to the ground nor the weather, and suffers racist remarks. Failing to join the main team, he is reduced to working clandestinely on a boat and despite his wishes to return home, his father's words "you must work, save and return" (Diome [2003] 2005: 104), ${ }^{14}$ are a litany that compels him to face his misery alone. Caught as an illegal immigrant, he is incarcerated before being sent back to Senegal. His failure to return successful and rich, leads to society rejecting him and his presence and eventually he commits suicide. His inability to accomplish his task as a man erodes his sense of identity. Moussa's story should serve as a deterrent to the youth, but it is perceived as an exception by most. For the majority of those who stay in France, Salie states "Africans of all origins live mostly in slums. Nostalgic, they dream of an improbable return to their origins, a country, which ultimately worries them more than attracts them, as, not having 
seen it change, they feel like strangers during their rare holidays" (Diome [2003] 2005: 176).

Diome's Salie continues to explore the pitfalls of living in a predominently white society thus: "In Europe, my brothers, you are first and foremost Black, incidentally citizens and definitely strangers, and that is not written in the Constitution, but it is read on your skin" (Diome [2003] 2005: 176). Ill at ease back "home" because they and the country have changed, and in France because they are Black, they experience an extreme sense of psychological dislocation, which Fanon analysed in Peau noire, masques blancs. Diome, like Miano, demonstrates that French society's perception of Black men has not altered in the last five decades and Pap Ndiaye's sociological study La Condition noire is testament to that.

\section{Finding a "Home": Re-inscribing African Migrant Masculinities in France}

The affectivity of home is bound up with the temporality of home, with the past, the present and the future. It takes time to feel at home. For those who have left their homes, a nostalgic relation to both the past and home might become part of the lived reality of the present. (Ahmed et al. 2003: 9)

Ahmed's description of the tension between host and home country is emblematic of the condition of migrants in both Diome's and Miano's texts. According to Gunew:

the term "nostalgia" derives from the Greek, combining a "return home" and "pain"; a prolonged absence from home, homesickness. In the index to Freud's collected works the closest term to nostalgia is Heimweh a pregnant term containing the home, the mother, sickness for but also of the home. (Gunew 2003: 47)

The lived experience of migration is fraught and while those who remain in the home country assume it to be a blissful experience, reality reveals itself to be otherwise, especially when the movement from periphery to centre is experienced as an exile.

For Said, "[Exile] is the unhealable rift forced between a human being and a native place, between the self and its true home: its essential sadness can never be surmounted" (Said 1990: 357). Amok, in Tels des astres éteints describes the nostalgia he experiences thus: "he missed the land. Its colours. Its seasons. The brightness of its mornings. The weight of the sky before rain. The movement of strangers on the streets" (Miano [2008] 2010: 30), ${ }^{15}$ but Amok's poetic memories are marred by those of his violent father. Amok's father is the son of a war collaborator and this legacy is passed down in his family, along with violence. Amok's father represents violence and his mother endurance for all the years she tolerated his beatings. Symbolically, Amok's father could also represent the old French regime and his mother, enduring Africa.

Yet, ironically, Amok's escape takes him to France, the very seat of Colonial power which he resents because of his grandfather. However, he chooses France because he could obtain funding for his studies, through his father's connections. Staying in France becomes a way of obtaining a tabula rasa, because he has no genealogy. Thus, whilst Shrapnel and Amandla in Miano's text and Salie in Diome's see migration as a purely economic endeavour-whereby migrant men cross the border for financial gains-Amok perceives migration to France as a means of finding a "virgin space to deploy the energy that the motherland was crushing. He understood more than anyone the feeling of freedom which one could experience by living where there was no past. It was like being 
born again" (Miano [2008] 2010: 41). ${ }^{16}$ Thus, with Amok, Miano explores the possibilities of creating a new mode of thinking the Black masculine identity in France.

According to Gedalof, "the female body is repeatedly appropriated as a marker of national, racial, religious and ethnic communities." Moreover, "by associating the female body with community origins, many identity narratives position 'Woman' as 'place,' as the pure space of 'home' in which tradition is preserved from outside contamination" (Gedalof 2003: 95). However, in Tels des astres éteints, Amok underscores the impossibility for migrants of possessing this woman-land. Indeed, he observes that migrants only return home for occasional holidays "because they could not withstand a massive dose of native land. The country was like someone else's woman. One could touch her a little. Never possess her" (Miano [2008] 2010: 42). ${ }^{17}$ For Amok, migrants perceive their home country as a woman who is slightly out of reach and not completely theirs, which increases their attraction towards it.

However, Amok's perception of home is not coloured by nostalgia. Here personal history influences the perception of the home country. His relationship with his parents and especially his mother reveals a man who has experienced a great deal of issues whilst negotiating his identity back "home." As child his mother "despaired to make a man out of him. He was so afraid. So melancholic. It was why she was stern. Not hesitating to beat him. To harden him. To see him rebel against his parents reassured her. He was a boy. He had acted like one" (Miano [2008] 2010: 34). ${ }^{18}$ The accumulation of short sentences, the staccato rhythm and sharp statements reflect the harsh upbringing that shapes Amok's masculinity. The description of Amok as an emotional man jars with traditional notions of masculinity in Cameroon, and thus it is only when he misbehaves that "they found him virile. Because they conceived masculinity as a big mess" (34). ${ }^{19}$

Similarly, Shrapnel, his best friend defines Black masculinity as the opposite of Amok:

a normally constituted Black could not be constantly be feeling the blues. He would not withdraw into himself. A well-configured Black man shouted, fought, and fucked. He expulsed his pain into another's heart and went on happily with his life. (Miano [2008] 2010: 53) $)^{20}$

Shrapnel's definition is problematic as it is generalized and reductive. Like Amok's mother, he looks to his society's values to gauge what "normal" is and meantime petrifies masculinity into a specific mould, which is accepted back home. Yet, with Amok, Miano introduces a new conception of Black masculinity, which is individual and personal. In this way, in Marianne et le garçon noir, Miano asserts that: "in a world environment structured and directed by male willpower, by virile rivalries or solidarities, it is useful to explore the masculinity of men who are seemingly devoid of power" (Miano 2017: 30). ${ }^{21}$

Writing about her own son's impending coming of age and blatant masculinity, Audre Lorde (1984) urges mothers to teach their sons how to feel and in facing their feelings, to become better human beings. Conversely, Amok's mother tries to stop him from feeling and incites rebellion in him. Later, faced with the pressure from Amandla to perform his masculinity, he experiences erectile dysfunction (Miano [2008] 2010: 253-54). Afraid to be his father's son, he does not want to procreate and cannot perform his masculinity. For Amok, becoming a man begins with rejecting his prior identity as his parents' offspring.

Thus, nostalgia has no part to play in Amok's negotiation of identity, as he adopts his own mode of thinking and living that does not rely on his legacy. Through him, Miano gives us a possible conceptualization of identity: 
Identities would not be national but borders. Borders would be a long juxtaposition. Rather than a scar impeding the unity of humanity. Men would have their common destiny. Their superficial differences would entertain them. Enrich them. If racism disappeared, there would be no need to valorise colour. (Miano [2008] 2010: 117)22

It is by no means a coincidence that he is the only character who is focused on finding himself rather than a collective identity that utters these words of hope for the future. Identity for Miano remains something that is still being negotiated and in the border. ${ }^{23}$

Moreover, according to Fortier, "leaving home or returning home are about moving between homes" (Fortier 2003: 130). When Amok takes Shrapnel's body back "home," he realises that just as his life has progressed and moved along, so has his country and he has not been part of these changes, of this history. The migrant remains in-between homes, but needs to recognize that both the home and s/he has changed in the process. Recognizing this change leads to another tabula rasa for Amok, who at the end returns "home" to Paris but does not take on the burden of creating a genealogy with Amandla. Ultimately his choice marks a new beginning for his own conception of masculinity as self-creating and feeling.

On the other hand, home and masculinity are envisaged in a different manner by Diome. Like Shrapnel and Amok, Salie also gives us a description of masculinity in Senegal. For her:

men did not like details, they say, from childhood they had already made him [her brother] understand that he act like a man. They had taught him to say "ouch!," to bite his tongue, to not cry when he was in pain or afraid. [...] They had erected a throne for him on the head of the feminine gender. Thus male, and proud to be so, this authentic guelwaar knew, even as a child, how to enjoy a princely hegemony [... ] and have the last word in front of the females. (Diome [2003] 2005: 40-41) ${ }^{24}$

However, Salie is not one of the "females" who submits to her brother because nothing in the world would make her want his testicles (Diome [2003] 2005: 41). While she is loving and will watch football matches for him, she uses it as a means of establishing constant communication with her brother. Indeed, Salie is deeply marked by nostalgia so much so that she calls herself an "exile." Cazenave distinguishes between migrants and exiles as, for her, the migrant has a specific destination. Diome's choice to give Salie the status of an exile is crucial to our understanding of place and identity in her text.

For Salie, globalization is positive because it gives the impression of belonging to the world even if one does not feel one belongs to the host nor the home country. Like Derrida's stranger (1997) who is outside of Reason (Logos) by virtue of being born elsewhere and can thus be perceived as mad, Salie feels fragmented. Yet, in her inbetween position, she is able to see the society she hails from, from an outsider perspective. Thus, she remarks that virility is a fragile throne (Diome [2003] 2005: 42) since boys and men are constantly required to hide their feelings and assert their masculinity. Moreover, through Moussa's story, she highlights the fact that his close friendship with Ndétare is seen as homosexual because there is no homosocial space in their society.

However, just like Moussa experienced exile in France, Ndétare was exiled to Niodior. Their closeness is only possible because they have experienced the same dislocation which is felt by those who have been in exile. They understand each other's suffering in more ways than those who have never left. The return home for Moussa is fraught and leads to implosion, psychological dislocation and ultimately to suicide. The men who have 
lived through exile cannot access home again because they have both changed. Like Amok, in Miano's novel, Moussa cannot come to terms with his home country and the changes operating both within himself and in the society around him. Unlike Amok, who has the possibility to return to France, Moussa can only deliver himself to the sea and ultimately commits suicide. Salie herself notes: "leaving is dying of absence. One can return, of course, but one returns as an other" (Diome [2003] 2005: 227). ${ }^{25}$

This "othered" masculinity is also explored with El Hadji, another character who had spent decades in France and who has undertaken return migration. The community believes that he is monogamous to imitate the Western marriage model assimilated while he was abroad, but more pointedly they call him "monotesticle" because the concept of masculinity is directly related to polygamy in the society depicted by Diome. Here, there is a tension between original and acquired culture. Ironically when El Hadji concedes and takes another wife after his return, his marriage is unsuccessful. Diome, through Salie's character delivers a message to the young men who wish to change their life:

ok fine, be ready to leave, go towards a better existence, but not with these suitcases, with your neurons! Dis-emigrate from your heads these habits that shackle you to an anachronistic mode of living. Polygamy, profusion of kids, all these constitute the fertile soil of under-development. (Diome [2003] 2005: 179) ${ }^{26}$

The power of education and thought is emphasized here as Diome wants Senegalese society to see where development lies instead of necessarily migrating to France. Salie's thought that it is perhaps because France has a woman's name that she is so desired unveils the deeply masculine need to travel and acquire France, when one lives in Africa, whereas the reverse journey reveals a deep-seated feeling of not-belonging or being inbetween identities. For Salie, like Amok, life in Africa was problematic because she had a tainted past, wherein she was born out of wedlock and was never recognised as being part of the community, even when her stepfather married her mother. Always different, she was the tomboy of the house, the only girl who could share the closed space for debates reserved for the boys because "each full exercise book, each read book, each consulted dictionary was an additional brick added to the wall separating her and the women" (171). Excluded from domestic spaces, Salie becomes an honorary man, in her household, following Bourdieu's definition of the spaces occupied by men and women in $L a$ Domination masculine (1998).

\section{Conclusion: Alternative Masculinities}

"Are alternatives to classic masculinity being put in place so that the individual overcomes norms and invents new spaces for himself?" asks Miano in Marianne et le garçon noir (Miano 2017: 27). Miano, as demonstrated above is in favour of alternative masculinities that would show that men can be sensitive and that this does not preclude them from seeing themselves as men. What she advocates is: "redefining masculinity by learning from those for whom it is constructed on the loopholes created by history" (32). Thus, rather than a focus on nostalgia and the past, Miano solidifies the need for shifting perceptions to the present of migrant masculinities.

In creating Amok, in Tel des astres éteints Miano reshapes masculinity as full of emotions and introspective. The power of affect is both to affect and to be affected and Miano depicts a man who is central to the narrative both as the first main protagonist but also as the focal point of all relationships. With Amok, Miano demonstrates that it is possible 
for immigrants to find their identity in the frontiers between the old home and the new home and that the stability that immigrants seek is perhaps inside them. Similarly, Diome redefines masculinities in Le Ventre de l'Atlantique: "no one has taught the men from our society that tenderness does not remove one's virility, that, on the contrary, it gives an additional soulfulness to the strongest of characters" (250). ${ }^{27}$

For both Amok and Salie, it is access to education and to a different thought process that allows them to see identity as something that is constantly negotiated. In Salie's case, as Connell (1995) has argued, women can also display signs of dominant or hegemonic masculinity. Salie's executive decision to send money to her brother for him to set up a business and not migrate to France leads to his financial stability. Salie and Amok feel out of place in Africa and France is not yet home, but it is the space which affords them the ability to renegotiate identity and ultimately, what it means to be "home."

\section{BIBLIOGRAPHY}

Ahmed, Sarah, Castañeda, Claudia et al., 2003, Uprootings/Regroundings: Questions of Home and Migration, Oxford, Berg.

Anzaldúa, Gloria, 1987, Borderlands/La Frontera: The New Mestiza, San Francisco, Aunt Lute.

Bhabha, Homi, 1994, The Location of Culture, London, New York, Routledge.

Bourdieu, Pierre, 1998, La Domination masculine, Paris, Seuil.

Boym, Svetlana, 1995, "Post-Soviet Cinematic Nostalgia: From 'Elite Cinema' to Soap Opera," Discourse, Vol. 17, No. 3, "Views from the Post-Future/Soviet and Eastern European Cinema," pp. 75-84.

Boym, Svetlana, 2001, The Future of Nostalgia, New York, Basic Books.

Cazenave, Odile, 2003, Afrique sur Seine : une nouvelle génération de romanciers africains à Paris, Paris, L'Harmattan.

Cazenave, Odile and Célérier, Patricia, 2011, Contemporary Francophone African Writers and the Burden of Commitment, Charlottesville, University of Virginia Press.

Cohen, Robin, 1997, Global Diasporas: An Introduction I, London, UCL Press.

Connell, Raewynn, 1995, Masculinities, Cambridge, Polity Press.

De Sondy, Amanullah, 2015, The Crisis of Islamic Masculinities, London, Bloomsbury.

Derrida, Jacques, 1997, Anne Dufourmantelle invite Jacques Derrida à répondre De l'hospitalité, Paris, Calmann-Lévy.

Diome, Fatou, [2003] 2005, Le Ventre de l'Atlantique, Paris, Livre de Poche.

Diome, Fatou, [2006] 2008, The Belly of the Atlantic, translated by Ros Schwartz and Lulu Norman, London, Serpent's Tail.

Etoke, Natalie, 2010, Melancholia Africana : l'indispensable dépassement de la condition noire, Paris, Le Cygne. 
Fanon, Frantz, 1952, Peau noire, masques blancs, Paris, Seuil.

Fortier, Anne-Marie, 2003, "Making Home: Queer Migrations and Motions of Attachment," in S. Ahmed, C. Catañeda et al., Uprootings/Regroundings: Questions of Home and Migration, Oxford, Berg, pp. 115-35.

Gedalof, Irene, 2003, "Taking a Place: Female Embodiment and Re-grounding of Community," in S. Ahmed, C. Catañeda et al., Uprootings/Regroundings: Questions of Home and Migration, Oxford, Berg, pp. 91-112.

Gilroy, Paul, 2004, Postcolonial Melancholia, New York, Columbia University Press.

Gunew, Sneja, 2003, "The Home of Language: A Pedagogy of the Stammer," in S. Ahmed,

C. Catañeda et al., Uprootings/Regroundings: Questions of Home and Migration, Oxford, Berg, pp. 41-

58.

Kimmel, Michael, 2010, Misframing Men: The Politics of Contemporary Masculinities, New Jersey, Rutgers University Press.

Lorde, Audre, 1984, Sister Outsider: Essays and Speeches, New York, Crossing Press.

Miano, Léonora, [2008] 2010, Tels des astres éteints, Paris, Pocket.

Miano, Léonora, 2017, Marianne et le garçon noir, Paris, Pauvert.

Ndiaye, Pap, 2008, La Condition noire : essai sur une minorité française, Paris, Gallimard, coll. « Folio Actuel ».

Said, Edward, 1990, "Reflections on Exile," in R. Ferguson, M. Gever, T.T. Minh-ha, and C. West (eds.), Out there: Marginalization and Contemporary Cultures, New York, Cambridge, New Museum of Contemporary Art and MIT press.

Tsuda, Takeyuki, 2009, “Introduction: Diasporic Return and Migration Studies," in T. Tsuda (ed.), Diasporic Homecomings: Ethnic Return Migration in Comparative Perspective, Stanford, Stanford University Press, pp. 1-21.

Van Klinken, Adriaan, 2016, "Pentecostalism, Political Masculinity and Citizenship: The BornAgain Male Subject as Key to Zambia's National Redemption," Journal of Religion in Africa, vol. 46, no. 3, pp. 129-57.

\section{NOTES}

1. "Ce qu'on appelle l'âme noire est une construction du Blanc." All translations from the French are mine.

2. On the African continent itself the relationship between religion and masculinities has recently been examined through the prism of Islam (De Sondy 2015) and Christianity (Van Klinken 2016), which is testament to the growing interest in masculinities postcolonialism.

3. For more on this see Kimmel's analysis on contemporary global masculinities (2010).

4. Pap Ndiaye gives an account of the different types of migrations from Africa in $L a$ Condition noire (2008) and focuses on the social alienation of Black migrant workers who were isolated and away from their families in order to provide for them.

5. "La plupart de ces garçons ne reçoivent que des bouches à nourrir en guise d'héritage. Malgré leur jeune âge, beaucoup sont déjà à la tête de famille nombreuses et on attend 
d'eux ce que leurs pères n'ont pas réussi : sortir les leurs de la pauvreté. Ils sont harcelés par des responsabilités qui les dépassent et les poussent vers les solutions les plus désespérées."

6. For more information on this see documentary by Alice Diop, for example "Mieux réfléchir à la fracture sociale de la France" accessed on 23rd Oct 2017 at https:// www.youtube.com/watch?v=m57T1HKJ9Vc.

7. Pap Ndiaye's interview in Le Monde Afrique, "Gommer le mot 'race' de la Constitution est un recul," highlights the dangers of removing the word "race" as it was used simply as a "point d'appui," an imaginary construct, to discourage those who discriminate. Its importance was fundamental in the wake of WWII but equally now. For Ndiaye, it is the opportunity to condemn the crime itself that has been deleted along with the word. Accessed online on $20^{\text {th }}$ September 2018 at https://www.youtube.com/watch?v=hH_5ilyfWc.

8. "[...] la perte, le deuil et la survie."

9. This notion is echoed by Alice Diop in her film "Vers la tendresse," which received the César in the short film category in 2017.

10. Interestingly Martin Luther King and Malcolm X represent Black Christian and Black Muslim masculinities, which reflect both Cameroonian and Senegalese masculinities present in the novel. Miano subtly also debunks the idea of Black redemption through religious discourses.

11. "Ils avaient peur de se trouver tout à coup sur cette terre qu'il était facile d'idéaliser de loin, où il n'y avait pas de métro, pas de Sécurité sociale. Peur de se retrouver parmi des gens qui ne les attendaient pas, qui ne les connaissaient pas, qui ne comprendraient pas qu'ils aient quitté Babylone pour rejoindre ce qu'ils fuyaient quant à eux. [...]. Elle connaissait de nombreuses personnes nées à Kemet, déterminées à n'y pas retourner. Elle en voyait tous les jours dans les rues de la ville, s'agripper à la misère de l'hémisphère Nord, persuadés qu'elle était plus glorieuse que celle de Kemet."

12. "[...] l'homme mythique."

13. “[...] il avait été un nègre à Paris [...] Jamais ses récits torrentiels ne laissaient émerger l'existence minable qu'il avait menée en France. [...] il avait d'abord hanté les bouches de métro, chapardé pour calmer sa faim, fait la manche, survécu à l'hiver grâce à l'Armée du Salut avant de trouver un squat avec des compagnons d'infortune."

14. "Tu dois travailler, économiser et revenir au pays."

15. "La terre lui manquait. Ses couleurs. Ses saisons. L'éclat de ses matins. La lourdeur de son ciel avant la pluie. Le mouvement des inconnus dans la rue."

16. “[...] un espace vierge où déployer l'énergie que la terre natale écrasait. Il comprenait mieux que personne le sentiment de liberté qu'on pouvait éprouver à vivre là où on n'avait pas de passé. C'était comme renaître."

17. "[...] ils ne pouvaient supporter une dose trop massive de terre natale. Le pays, c'était comme la femme d'un autre. On pouvait la toucher un peu. Jamais la posséder."

18. “[...] elle désespérait d'en faire un homme. Il était si craintif. Tellement mélancolique. C'était pour cela qu'elle se montrait sévère. Pour l'endurcir. Le voir soudain se dresser contre ses parents l'avait rassurée. Il était un garçon. Il s'était comporté comme tel."

19. "On le trouvait viril. Parce qu'on concevait la masculinité comme une espèce de grand désordre." 
20. “Un Noir normalement constitué ne pouvait être en proie au vague à l'âme. Il ne se repliait pas sur lui-même. Un homme noir bien configuré criait, se battait, s'envoyait furieusement en l'air. Il expulsait sa douleur, la déposait dans un autre cœur, et vaquait dans l'allégresse à son existence."

21. "Dans un environnement mondial structuré et régi par des volontés mâles, par des rivalités ou des solidarités viriles, il est utile d'explorer le rapport à leur masculinité d'hommes en apparence privés de pouvoir."

22. "Les identités ne seraient pas nationales mais frontalières. Les frontières seraient un long côte-à-côte. Plutôt qu'une cicatrice barrant l'unité du genre humain. Les hommes sauraient leur destin commun. Leurs différences superficielles les divertiraient. Les enrichiraient. Si le racisme disparaissait, il n'y aurait plus à valoriser la couleur."

23. Much like Anzaldúa's concept of "border consciousness" (1987) wherein the individual can live at the crossroads of cultures.

24. "Les hommes n'aimaient pas les détails, dit-on, et lui, tout petit déjà, on lui avait fait comprendre qu'il devait se comporter en homme. On lui avait appris à dire 'ouille !', à serrer les dents, à ne pas pleurer lorsqu'il avait mal ou peur. [...] on lui avait bâti un trône sur la tête de la gent féminine. Mâle donc, et fier de l'être, cet authentique guelwaar savait dès l'enfance, jouir d'une hégémonie princière [...] et avoir le dernier mot devant les femelles."

25. "Partir, c'est mourir d'absence. On revient certes, mais on revient autre."

26. "D'accord, soyez prêts au depart, allez vers une meilleure existence, mais pas avec des valises, avec vos neurones! Faites émigrer de vos têtes certaines habitudes bien ancrées qui vous chevillent à un mode de vie révolu. La polygamie, la profusion d'enfants, tout cela constitue le terreau fertile du sous-développement."

27. “[...] nul n'a appris aux hommes de chez nous que la tendresse n'ôte de virilité à personne, qu'elle donne au contraire un supplément d'âme au plus affirmé des caractères."

\section{ABSTRACTS}

Fatou Diome and Léonora Miano, both born in Africa and living in France, are part of the growing number of diasporic West African writers seeking to transform the landscape of African literature. In this article, I will examine the emerging notions of masculinity in relation to West African migrants in Paris to gauge the extent to which the women writers are reconceptualising masculine identity, and thus debunking erstwhile notions of masculinity. This article analyses how Miano and Diome reshape and reconstruct African masculinities in post-colonial, contemporary France, where nationalism and the need to assert French identity is becoming more prominent. The concept of nostalgia and its implied hope for a return are examined to determine whether the return is ever completely possible and how this shifts the conceptualization of masculinity. Moreover, the tension between the new home and the original home and their role in identity construction is analysed to demonstrate whether the emergent Black masculinities depicted display a new way of reshaping masculinity. 
Fatou Diome et Léonora Miano, nées en Afrique et habitant en France, font partie d'un nombre croissant d'auteurs de la diaspora africaine qui cherchent à transformer la littérature africaine. Dans cet article nous examinerons les notions de masculinité émergentes liées aux immigrants africains à Paris, afin de démontrer jusqu'à quel point ces autrices reconceptualisent l'identité masculine et discréditent les notions obsolètes de masculinité. Cet article démontre, à travers des analyses de textes, que Miano et Diome reconstruisent les masculinités africaines dans une France post-coloniale, où le nationalisme et l'identité française sont prééminents. La nostalgie et l'espoir de retour que celle-ci implique seront analysés afin de déterminer si le retour est possible et comment cela pourrait changer le concept de masculinité. De plus, la tension entre le nouveau "chez soi » et le "chez soi » d'origine et sa fonction dans la construction identitaire sera analysée afin de démontrer si oui ou non les masculinités noires émergentes sont une nouvelle manière de conceptualiser l'identité masculine.

\section{INDEX}

Keywords: migrant African literature, gender, masculinities, identity construction, immigrant identity, Diome (Fatou), Miano (Léonora)

Mots-clés: Afrique, genre, masculinités, construction des identités, identité des immigrés, Diome (Fatou), Miano (Léonora)

\section{AUTHOR}

\section{ASHWINY O. KISTNAREDDY}

University of Cambridge 